\title{
KONSTRUKSI PESAN TARI 'KECAK' PADA MASYARAKAT BADUNG, BALI
}

\author{
Sumiati ${ }^{1)}$ dan Lasmery RM Girsang ${ }^{2)}$ \\ 1) Ilmu Komunikasi, Universitas Bunda Mulia \\ 2) IImu Komunikasi, Universitas Bunda Mulia
}

Disetujui 26 Februari 2018

\begin{abstract}
Bali becomes the world's tourism that has varied culture, one of them is 'Tari Kecak' ('Tari Cak' or 'Fire Dance'). Different with other dance using music ('gamelan'), 'Tari Kecak' just uses the dancer's sound/shouting like "cak cak ke cak cak ke" as the art. Through qualitative research based on constructive paradigm, the researcher depended on participative observation and in depth interview to the key informants and informants (from local society and tourists). By using Semantic Meaning Theory from Charles Osgood, the results show five meanings from 'Tari Kecak', namely (a) avoiding curse, (b) as a belief system, (c) as a holy thing, (d) as an art and culture and also (e) as economic income.
\end{abstract}

Keywords: Message, Tari Kecak, Semantic Meaning Theory

\begin{abstract}
ABSTRAK
Bali merupakan destinasi wisata dunia yang memiliki ragam budaya, salah satunya adalah Tari Kecak (biasa juga disebut sebagai Tari "Cak" atau Tari Api/fire dance). Berbeda dengan tarian lainnya yang menggunakan alat musik (gamelan), tari Kecak hanya memadukan seni dari suara para penari berupa teriakan-teriakan seperti "cak cak ke cak cak ke". Pada penelitian kualitatif dengan paradigma konstrukstivis ini, peneliti mengedepankan pengamatan partisipatif dan wawancara mendalam kepada enam narasumber (baik warga di Bali maupun wisatawan asing). Dengan menggunakan Teori 'Pengertian Secara Semantik' (Charles Osgood), hasil penelitian menunjukkan lima makna pesan dari Tari Kecak, yakni: (a) menghindari karma, (b) kepercayaan, (c) sakral, (d) seni dan budaya, serta (e) pendapatan ekonomi.
\end{abstract}

Kata Kunci: Pesan, Tari Kecak, Teori Pengertian Semantik

\section{PENDAHULUAN}

Sudah sangat lama, Bali dikenal sebagai ikon pariwisata dunia, salah satunya melalui seni tari. Diantara beragam seni tari yang ada, adalah tari 'Kecak'. Sebuah tarian unik yang tidak disaranai dengan alat musik, melainkan paduan seni dari suara-suara mulut atau teriakan-teriakan seperti "cak cak ke cak cak ke" disepanjang pertunjukan.

\footnotetext{
*Korespondensi Penulis:

E-mail: lgirsang@bundamulia.ac.id
}

Secara ringkas, tarian yang dipentaskan lebih dari 50 orang penari laki-laki atau perempuan yang duduk berbaris melingkar dengan irama tertentu dan sambil menyerukan "cak" serta mengangkat kedua tangannya. Para penari yang duduk melingkar mengenakan kain kotak-kotak (disebut kain poleng). Dengan latar belakang kisah Ramayana melawan Rahwana (raksasa) yang menculik Dewi Shinta (istri dari Ramayana) yang akhirnya berhasil diselamatkan Rahmana.

Sebenarnya, tari 'Kecak' berangkat dari ritual Sang Hyang, yaitu tradisi tarian yang penarinya akan berada dalam kondisi 
tidak sadar ketika melakukan komunikasi dengan para dewa atau roh para leluhur dan kemudian menyampaikan harapanharapannya kepada masyarakat.

Tari Kecak biasanya disebut sebagai tari "Cak" atau tari Api (Fire Dance) merupakan tari pertunjukan massal atau hiburan dan cenderung sebagai sendratari yaitu seni drama, karena seluruhnya menggambarkan seni peran yang tidak secara khusus digunakan dalam ritual agama seperti pemujaan, odalan atau upacara lainnya. Bentuk-bentuk sakral dalam tari Kecak ini biasanya ditujukan dalam hal kerauhan atau masolah yaitu kekebalan secara gaib sehingga tidak terbakar oleh api. Tarian tersebut merupakan satu dari sekian banyak tari tradisional khas Bali yang mampu menjadi daya tarik wisatawan domestik maupun asing yang datang ke Bali. Tari Kecak sendiri dapat disaksikan di area wisata Uluwatu pada setiap hari jam 18.00 WITA.

Seni tari merupakan salah satu jenis kesenian yang menggabungkan gerak dan suara menjadi sebuah wujud kebudayaan yang dapat dinikmati oleh semua orang. Sebagai bagian dari kesenian, seni tari juga merupakan bentuk ekspresi jiwa dalam masyarakat. Oleh sebab itu, biasanya seni tari selalu mengandung makna atau pesan tertentu. Seni tari juga sering dikatakan sebagai cabang kesenian yang sangat tua, sebab materi baku dari kesenian ini adalah gerak dan alat ungkap yang paling penting yakni tubuh manusia itu sendiri (Dibia dkk., 2006:24).

Melalui kesenian, manusia dapat mencapai kehidupan spiritual yang penuh kedamaian dan kesejahteraan sebagai tujuan hidup (Sudirga, 2005:1). Tentunya, hal tersebut merupakan suatu bentuk pernyataan bahwa dalam kehidupan manusia tidak serta merta hanya melihat aspek realitas, namun juga terdapat sisi abstrak melalui adanya kebutuhan spiritual. Tidak dapat dipungkiri pada sebagian besar masyarakat Indonesia, sisi spiritualitas merupakan salah satu 'jembatan' komunikasi yang dapat menghubungkan individu maupun kelompok manusia dengan yang lain. Oleh sebab itu, kesenian pun merupakan suatu produk komunikasi yang diciptakan manusia sebagai sesuatu yang dinamis dan hasil budaya asli daerah masing-masing.

Tentunya, setiap daerah di Indonesia memiliki kebudayaan khasnya masingmasing. Namun, seiring perkembangan zaman, warisan budaya yang sudah ada sejak jaman lampau ini tentunya mengalami pembaharuan. Pembaharuan dapat merupakan sebuah pencerminan dari semangat kreativitas seniman sebagai upaya pengolahan seni yang bersifat dinamis. Warisan kebudayaan yang turun temurun diwariskan kepada generasi kini, tentunya masih terjaga salah satunya akibat dari idealism para seniman. Tak hanya garis keturunan yang membuat warisan kebudayaan tetap lestari, namun jasa dari para seniman pun turut diapresiasi. Kreativitas yang mereka miliki untuk terus berinovasi terhadap hal-hal baru untuk ditampilkan, memicu semangat para pelakon seni untuk tetap melestarikannya.

Meskipun terjadi pembaharuan, tentunya bukan berarti bersifat destruktif sebab pembaharuan dapat terjadi jika terbentuk kesepakatan dari seluruh anggota masyarakat yang terkait. Termasuk tari Kecak yang berkembang pesat dan tetap bertahan keasliannya sampai sekarang.

Dari pemaparan sebelumnya, penulis tertarik untuk mengetahui:

1. Apa pesan yang terkandung dalam tarian Kecak?

2. Bagaimana pesan tari Kecak dapat dikonstruksikan ke dalam realitas kehidupan masyarakat Bali?

\section{KAJIAN PUSTAKA}

\section{Konstruksi}

Menurut Sarwiji (2008:63), yang dimaksud dengan makna konstruksi (construction meaning) adalah makna yang terdapat dalam sebuah konstruksi keabsahan (kebenaran). Jadi, makna konstruksi dapat diartikan sebagai makna yang berhubungan dengan kalimat atau kelompok kata yang ada didalam sebuah kata dalam kajian 
keabsahan. Konstruksi dapat juga didefinisikan sebagai susunan (model, tata letak) suatu bangunan (jembatan,rumah, dan lain sebagainya).

Kata 'konstruksi' ini dalam kenyataannya adalah konsep yang cukup sulit untuk dipahami dan disepakati kata konstruksi mempunyai beragam interpretasi, tidak dapat didefinisikan secara tunggal, dan sangat tergantung pada konteksnya. Beberapa definisi konstruksi berdasarkan konteksnya perlu dibedakan atas dasar: proses, bangunan, kegiatan, bahasa dan perencanaan.

\section{Pesan}

Terkait pesan, berikut diuraikan lebih terperinci. Pesan merupakan bagian dari unsur-unsur komunikasi. Dalam proses komunikasi, pengertian pesan adalah sesuatu yang disampaikan pengirim kepada penerima. Pesan dapat disampaikan dengan cara tatap muka atau melalui media komunikasi. Isinya bisa berupa ilmu pengetahuan, hiburan, informasi, nasihat atau propaganda (Cangara, 2011). Adapun definisi pesan menurut Laswell adalah seperangkat lambang bermakna yang disampaikan oleh komunikator". Sementara definisi lain, pesan adalah pernyataan yang didukung oleh lambang. Pesan dalam komunikasi terdiri atas dua jenis, yakni verbal dan non-verbal. Komunikasi nonverbal meliputi ekspresi wajah, postur, gesture (gerak tubuh sebagai isyarat), nada suara, sentuhan, penggunaan waktu secara sistematis, dan gerak-gerik fisik lainnya yang secara sengaja digunakan sebagai cara menyampaikan pesan. Sedangkan komunikasi verbal meliputi tiga kelompok disiplin, yakni sintaksis, semantik, dan pragmatis. Sintaksis berkaitan dengan hubungan antarkata, sedangkan semantik berhubungan dengan kata-kata dan perilaku. Sebagai komunikator, orang mengelola pesan-pesan melalui komunikasi verbal dan non-verbal guna menciptakan makna menurut konteks tertentu. (Effendy, 2005: $6)$.

Selanjutya, pesan yang disampaikan dalam proses komunikasi juga harus mempertahankan faktor-faktor yang menunjang keberhasilan pesan itu sendiri, diantaranya faktor isi pesan, teknik pengelolaan pesan dan teknik penyampaian pesan. Menurut Wilbur Schramm, jika kita menginginkan pesan, kita dapat membangkitkan tanggapan yang kita kehendaki maka ada kondisi yang harus dipenuhi ("the condition of success in communication"). Kondisi tersebut dirumuskan sebagai berikut:

1. Pesan harus dirancang dan disampaikan sedemikian rupa, sehingga dapat menarik perhatian komunikan.

2. Pesan harus menggunakan lambanglambang tertuju kepada pengalaman yang sama dan komunikan, sehingga sama-sama mengerti.

3. Pesan harus membangkitkan kebutuhan pribadi komunikan dan menyarankan beberapa cara untuk memperoleh kebutuhan tersebut.

4. Pesan harus menyarankan suatu jalan untuk memperoleh kebutuhan tadi yang layak bagi situasi kelompok di mana komunikan berada pada saat ia digerakkan untuk memberikan tanggapan yang dikehendaki (Effendy, 1993:41).

Lebih jauh menurut Cassandra ada dua model dalam penyusunan pesan yaitu; "penyusunan pesan yang bersifat informatif" dan "penyusunan pesan yang bersifat persuasif" (dalam Cangara, 2004: 121-125). Berikut adalah penjelasan mengenai penyusunan pesan tersebut:

1. Penyusunan pesan yang bersifat informatif.

Model penyusunan pesan yang bersifat informatif lebih banyak ditujukan pada perluasan wawasan dan kesadaran khalayak. Prosesnya lebih banyak bersifat difusi atau penyebaran, sederhana, jelas dan tidak banyak menggunakan istilah yang kurang populer di khalayak. Ada empat macam penyusunan pesan yang bersifat informatif, yakni:

a. Space Order, ialah penyusunan pesan yang melihat kondisi tempat 
atau ruang, seperti internasional, nasional dan daerah.

b. Time Order, ialah penyusunan pesan berdasarkan waktu atau periode yang disusun secara kronologis.

c. Deductive Order, ialah penyusunan pesan mulai dari hal-hal yang bersifat umum kepada yang khusus.

d. Inductive Order, ialah penyusunan pesan yang dimulai dari hal-hal yang bersifat khusus kepada hal-hal yang bersifat umum.

2. Penyusunan pesan yang bersifat persuasif.

Model penyusunan pesan yang bersifat persuasif memiliki tujuan untuk mengubah persepsi, sikap dan pendapat khalayak. Sebab itu penyusunan pesan persuasif memiliki sebuah proposisi. Proposisi disini ialah apa yang dikehendaki sumber terhadap penerima sebagai hasil pesan yang disampaikannya, artinya setiap pesan yang dibuat diinginkan adanya perubahan. Selain itu, penyusunan pesan juga didapat dari berbagai teknik persuasi, antara lain:

a. Fear appeal, ialah metode penyusunan atau penyampaian pesan dengan menimbulkan rasa ketakutan kepada khalayak.

b. Emotional appeal, ialah cara penyusunan atau penyampaian pesan dengan berusaha menggugah emosi khalayak.

c. Reward appeal, ialah cara penyusunan atau penyampaian pesan dengan menawarkan janjijanji kepada khalayak.

d. Motivational appeal, ialah teknik penyusunan pesan yang dibuat bukan karena janji-janji, tetapi disusun untuk menumbuhkan internal psikologis khlayak sehingga mereka dapat mengikuti pesanpesan itu.

e. Humorious appeal, ialah teknik penyusunan pesan yang disertai humor, sehingga dalam penerimaan pesan khlayak tidak merasa jenuh.
Berhasil tidaknya sebuah pesan diterima oleh komunikan sesuai dengan keinginan komunikator, maka dalam pembuatan pesan pun harus memperhatikan faktor penyampaian pesan. Menurut Siahaan (1991: 33), ada sembilan hal yang harus diperhatikan dalam penyampaian pesan:

1. Pesan itu harus cukup jelas (clear)

2. Pesan itu mengandung kebenaran yang sudah diuji (correct)

3. Pesan itu ringkas (concise)

4. Pesan mencakup keseluruhan (comprehensive)

5. Pesan nyata (concrete)

6. Pesan lengkap (complete) dan disusun secara sistematis

7. Pesan menarik dan meyakinkan (convincing)

8. Pesan disampaikan dengan sopan (courtesy)

9. Nilai pesan itu sangat mantap (consistent).

Pada akhirnya, O'Keefe (dalam Littlejohn 2009: 188-189) menegaskan tiga logika penyusunan pesan yakni:

a. Logika ekspresif (person centered) dimana komunikasi mengungkapkan perasaan dan pemikiran sendiri, pesanpesan bersifat terbuka dan reaktif dengan sedikit perhatian pada kebutuhan/keinginan orang lain.

b. Logika konvensional (rhetorical logic) dimana komunikasi sebagai sebuah permainan yang dimainkan dengan logika yang menyusun pesan secara sopan, tepat dan aturan-aturan yang diketahui semua orang.

c. Logika retoris dimana komunikasi sebagai sebuah cara perubahan aturan melalui negoisasi sehingga cenderung fleksibel, berwawasan dan terpusat pada seseorang

\section{Semantic Meaning Theory (Teori Pengertian Secara Semantik)}

Charles Osgood, seorang psikolog sosial terkemuka pada tahun 1960-an, mengembangkan salah satu teori yang paling berpengaruh tentang makna. Pada masa itu, psikologi didominasi oleh ilmu perilaku, 
tetapi pendekatan kognitif baru saja mulai populer; teorinya sebenarnya memiliki dasar di kedua tradisi tersebut. Teori Osgood berhubungan dengan cara-cara mempelajari makna dan bagaimana makna tersebut berhubungan dengan pemikiran dan perilaku. Sekarang dianggap sebagai sebuah karya, teori Osgood adalah sebuah tempat berguna untuk mulai berpikir tentang bagaimana lawan bicara memahami pesan.

Osgood dan yang lainnya telah melakukan penelitian semantik yang berbeda terhadap beragam jenis konsep, termasuk kata-kata, musik, seni, dan bahkan suarasuara sonar, mereka telah meneliti bahwa konsep ini ada dalam cakupan budaya yang luas juga. Osgood menyakini bahwa ketiga konsep pemaknaan evaluasi, aktivitas, dan potensi berlaku pada semua orang dan semua konsep.

\section{METODOLOGI PENELITIAN}

\section{Metode Penelitian}

Dalam penelitian ini, peneliti menggunakan metode penelitian kualitatif yang berlandaskan pada filsafat postpositivisme, digunakan untuk meneliti pada kondisi objek yang alamiah (sebagai lawannya adalah eksperimen), dimana peneliti sebagai instrumen kunci, pengambilan sampel sumber data dilakukan secara purposive dan snowball, teknik pengumpulan dengan triangulasi (gabungan), analisis bersifat induktif / kualitatif, dan hasil penelitian kualitatif lebih menekankan makna daripada generalisasi.

Adapun pandangan dasar dalam penelitian kualitatif:

1. Realitas sosial adalah sesuatu yang subjektif dan diinterpretasikan, bukan sesuatu yang berada diluar individuindividu.

2. Manusia tidak secara sederhana (tidak begitu saja) mengikuti hukum-hukum alam diluar diri mereka, melainkan menciptakan rangkaian makna dalam menjalani hidupnya.
3. Ilmu didasarkan pada pengetahuan sehari-hari, bersifat induktif, idiografis dan tidak bebas nilai.

4. Penelitian bertujuan untuk memahami kehidupan sosial (Sarantakos, 1993).

Juga, penelitian kualitatif terdiri dari:

a. Penelitian Interaktif

Penelitian ini ditandai dengan adanya interaksi antara peneliti dengan yang diteliti. Dalam pengumpulan data terdapat proses komunikasi langsung antara peneliti dengan yang diteliti (individu, kelompok sosial atau masyarakat). Data penelitian diperoleh langsung dari informan atau subjek penelitian atau partisipan dari peristiwa yang diteliti melalui wawancara atau observasi atau pengamatan.

b. Penelitian Non-Interaktif

Penelitian ini dilakukan dengan menganalisis data skunder atau data dalam bentuk laporan, teks, atau artefak yang tidak melibatkan informan atau partisipan sebagai pemberi data langsung (Pujileksono, 2006: 14).

\section{Paradigma Penelitian}

Dalam penelitian ini, paradigma yang digunakan adalah paradigma interpretif/paradigma konstruktivis. Paradigma interpretif/ paradigma konstruktivis memandang ilmu sosial sebagai analisis sistematis terhadap tindakan yang berarti secara sosial (socially meaningful action) melalui pengamatan langsung atau terperinci terhadap para pelaku sosial dalam setting sehari-harinya yang alamiah, agar mampu memahami dan menafsirkan bagaimana para pelaku sosial yang bersangkutan menciptakan dan memelihara/ mengelola dunia sosial mereka.

Sarakantos membedakan paradigma interpretif/paradigma konstruktivis kedalam dua perspektif, yaitu dari perspektif keilmuan dan perspektif tujuan penelitian sosial. Dari perspektif keilmuan dijelaskan bahwa, pegetahuan dan pemikiran awam manusia berisikan arti (makna) yang diberikan individu terhadap pengalaman dan kehidupannya sehari-hari, dan hal 
tersebutlah yang menjadi langkah awal penelitian ilmu-ilmu sosial.

Sedangkan dari perspektif tujuan penelitian sosial dijelaskan bahwa, penelitian dilakukan untuk mengembangkan pemahaman: membantu untuk memahami dan menginterpretasi apa yang ada dibalik peristiwa, latar-belakang pemikiran manusia yang terdapat di dalamnya, serta bagaimana manusia meletakkan makna pada peristiwa yang terjadi. Upaya-upaya mengendalikan atau meramal tidak menjadi aspek penting.

\section{Unit Analisis}

Unit analisis dari penelitian ini adalah konstruksi pesan pada tari Kecak. Peneliti melakukan wawancara mendalam dengan beberapa sumber yang peneliti pilih berdasarkan kebutuhan dan kepentingan dalam melengkapi data penelitian. Peneliti juga melakukan observasi dengan menonton tari Kecak secara langsung. Peneliti memilih ketua dan wakil ketua sanggar tari Kecak Uluwatu sebagai key informant. Sedangkan, informan yang peneliti wawancarai adalah dua orang masyarakat Bali dan dua orang wisatawan yang menyaksikan tari Kecak.

\section{Teknik Pengumpulan Data}

Data primer dalam penelitian ini diperoleh melalui wawancara mendalam dan observasi partisipan.

1. Wawancara Mendalam

Wawancara mendalam adalah metode yang memungkinkan pewawancara untuk bertanya kepada informan dengan harapan untuk memperoleh informasi mengenai fenomena yang ingin diteliti. Wawancara mendalam dilihat oleh peneliti sebagai sebuah kolaborasi antara pewawancara dan partisipan, dimana apa yang ingin didiskusikan oleh partisipan sama pentingnya dengan apa yang ingin didiskusikan oleh pewawancara. Para peneliti yang memilih wawancara mendalam tertarik terhadap arah yang ingin ditentukan oleh informan dalam wawancara. Mereka tidak mementingkan pengujian hipotesis melainkan mencari tahu pengalamanpengalaman informan. Wawancara mendalam biasanya dilakukan antara satu hingga tiga jam. Peneliti lebih tertarik dalam memperoleh data dan gambaran yang mendalam daripada mengumpulkan informasi dari ratusan informan. Selanjutnya, wawancara mendalam biasanya dilakukan oleh si peneliti sendiri (West dan Turner, 2010: 83).

2. Observasi

Observasi barangkali menjadi metode yang paling dasar dan paling tua dari ilmu-ilmu sosial, karena dalam cara-cara tertentu kita selalu terlibat dalam proses mengamati. Semua bentuk penelitian psikologis, baik itu kualitatif maupun kuantitatif mengandung aspek observasi di dalamnya. Istilah observasi diarahkan pada kegiatan memperhatikan secara akurat mencatat fenomena yang muncul, dan mempertimbangkan hubungan antar aspek dalam fenomena tersebut. Tujuan observasi adalah mendeskripsikan setting yang dipelajari, aktivitasaktivitas yang berlangsung, orang-orang yang terlibat dalam aktivitas, dan makna kejadian dilihat dari perspektif mereka yang terlibat dalam kejadian yang diamati tersebut (Poerwandari, 2005: 134-136).

\section{Teknik Keabsahan Data}

Teknik keabsahan data yang peneliti gunakan dalam penelitian ini adalah triangulasi metode. Triangulasi menurut Pujileksono (2015:144), triangulasi metode dilakukan dengan cara membandingkan informasi atau data dengan cara atau metode yang berbeda. Peneliti membandingkan data yang diperoleh dari metode wawancara dengan hasil observasi yang dilakukan oleh peneliti.

\section{Teknik Analisis Data}

Dalam penelitian ini teknik analisis yang digunakan adalah model interaktif Miles dan Huberman (Sugiyono, 2013:345) yaitu dimulai dari pengumpulan data, reduksi data, penyajian data, penarikan kesimpulan yang dikaji kedalam konstruksi pesan pada tari Kecak. Reduksi data 
merupakan proses pengumpulan data penelitian, seorang peneliti dapat menemukan kapan saja waktu untuk mendapatkan data yang banyak, apabila peneliti mampu menerapkan metode observasi, wawancara atau dari berbagai dokumen yang berhubungan dengan subjek yang diteliti. Maknanya pada tahap ini, peneliti harus bisa merekam data lapangan dalam bentuk catatan-catatan lapangan (field note), harus ditafsirkan atau diseleksi masing-masing data yang relevan dengan fokus masalah yang diteliti. Mereduksi data berarti merangkum, memilih hal-hal pokok, memfokuskan pada hal-hal penting, dicari tema dan polanya, dan membuang yang tidak perlu.
Tahap yang kedua adalah penyajian data. Dengan menyajikan data peneliti akan mudah memahami apa yang sedang terjadi, apa yang harus dilakukan, dan juga menganalisis serta mengambil tindakan berdasarkan atas pemahaman yang didapat dari penyajian tersebut. Dalam penyajian data diambil kesimpulan terkait konstruksi pesan yang tersirat pada tari kecak. Langkah ketiga dalam analisis data kualitatif menurut Miles da Hubermen adalah penarikan kesimpulan. Kesimpulan yang diambil akan ditangani secara longgar dan tetap terbuka sehingga kesimpulan yang semula belum jelas, kemudian akan meningkat menjadi lebih rinci dan mengakar dengan kokoh.

\section{HASIL DAN PEMBAHASAN}

\section{Profil Subjek Penelitian Key Informant 1:}

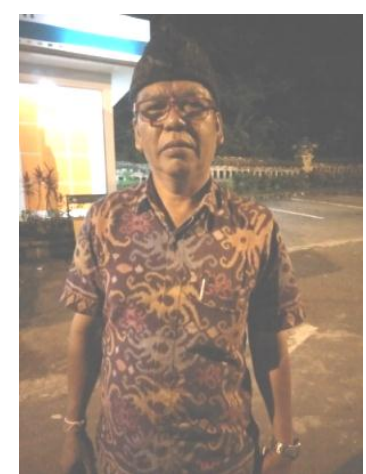

Gambar 1. Key Informant 1

Sumber: Peneliti

I Wayan Musin Arjani adalah ketua sanggar sekaligus pendiri pentas tari Kecak di Uluwatu. I Wayan tertarik dengan tari Kecak semenjak duduk dibangku sekolah, ia juga sering mengikuti kegiatan tari Kecak yang diselenggarakan oleh pemerintah daerah. Dimana tari Kecak pada saat itu masih belum terkenal seperti sekarang, dan tari Kecak yang dapat disaksikan secara komersil oleh masyarakat hanya terdapat di daerah Gianyar. Sehingga pada 1996, I Wayan memutuskan untuk mendirikan pentas tari Kecak di daerah Uluwatu, dengan harapan agar tari Kecak semakin dikenal masyarakat luar Bali maupun mancanegara.

Key informant 2 (tidak diberi ijin untuk menampilkan foto):

I Made Aste adalah wakil ketua sanggar dan pengajar tari Kecak Uluwatu. I Made Aste bergabung dengan sanggar tari Kecak Uluwatu sejak tahun 1999. Pria kelahiran Gianyar 7 februari 1956 ini bergabung dengan sanggar tari Kecak karena ia mencintai seni. 
Informan 1 (tidak diberi ijin untuk menampilkan foto):

I Made adalah seorang supir taksi yang memiliki empat orang anak. Ia sudah bekerja menjadi supir taksi di daerah wisata Bali selama 6 tahun terakhir. Sehingga beliau banyak mendapatkan masukan, komentar hingga pujian dari wisatawan yang berkunjung ke Bali, baik wisatawan lokal maupun mancanegara.
Informan 2 (tidak diberi ijin untuk menampilkan foto):

Ketut Polos adalah seorang penjaga pantai di salah satu hotel bintang 5 yang berlokasi di Nusa Dua, Bali. Pria kelahiran Klungkung, 17 Juni 1969 ini telah bekerja di hotel selama sepuluh tahun. Mengawasi tamu hotel yang bermain di tepi pantai hotel merupakan tugas yang sudah dijalani selama 3 tahun terakhir. Dari profesinya ini, ia banyak berkomunikasi dengan wisatawan mengenai hal-hal yang menjadi daya tarik dari Pulau Dewata, seperti kesenian, kebudayaan, hingga cinderamata yang unik.

\section{Informan 3:}

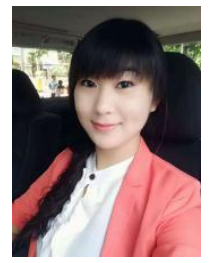

Gambar 2. Key Informant 3

Sumber: Peneliti

Edwina adalah wisatawan asal China. Sebelumnya Edwina juga sudah pernah berkunjung ke Bali sebanyak dua kali, sehingga ini merupakan perjalanan kali ketiganya ia mengunjungi pulau seribu Pura ini. Perempuan kelahiran Shanghai, 17 April
1987 ini mengakui ia sangat menyukai keindahan pantai di Bali dan juga kagum pada budaya masyarakat di Bali yang menurutnya tidak ditemukan di negara manapun.

\section{Informan 4:}

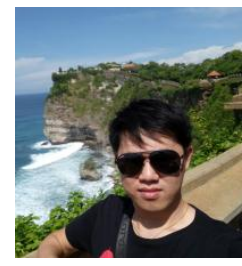

Gambar 3. Key Informant 4

Sumber: Peneliti

John Song adalah seorang wisatawan asal China yang pertama kali ke Bali dengan mengikuti tur. Pria kelahiran Fujian, 25 Juni 1992 ini mengatakan, Bali merupakan salah satu tempat yang membuatnya penasaran karena saat ini semua orang China berlomba-lomba ke Bali, sehingga Bali menjadi sangat terkenal di China.
HASIL PENELITIAN

Terkait makna pesan :

Key Informant 1:

"Masyarakat Bali sebagian besar agamanya Hindu. Di ajaran agama Hindu, selalu diingatkan tentang adanya reinkarnasi dan karma sebab akibat. Manusia memiliki kehidupan lampau maupun kehidupan yang 
akan datang, manusia tidak dapat melarikan diri dari ikatan karma. Apa yang kita perbuat akan kita terima nantinya, apa yang kita tanam itulah yang akan kita tuai. Karena percaya adanya karma, masyarakat Bali sangat menjunjung tinggi tentang kebaikan dan menghindari perbuatan jahat. Dengan harapan, perbuatan baik yang kita lakukan akan mendapatkan pembalasan yang baik juga dari para Dewa. Begitu juga perbuatan jahat, suatu hari nanti akan mendapatkan pembalasan yang buruk juga".

Berdasarkan jawaban dari key informant tersebut, peneliti melihat bahwa masyarakat Bali dalam menjalani kehidupan selalu mengingat adanya karma sehingga karma merupakan suatu pengingat bagi mereka dalam melakukan suatu tindakan.

"Tari Kecak menceritakan kisah antara Rama dan Shinta yang berhasil mengalahkan Rahwana seorang raja yang jahat. Cerita ini tidak jauh-jauh dari kepercayaan yang dianut oleh orang Bali. Tari Kecak mengandung makna bahwa orang baik selalu dilindungi para Dewa, jadi orang baik akan selalu menang, seperti Rama yang berhasil mengalahkan Rahwana seorang raja yang jahat"

Berdasarkan jawaban dari key informant peneliti melihat, bahwa tari Kecak ini bukan hanya tarian hiburan semata bagi masyarakat Bali. Kepercayaan yang dianut oleh masyarakat Bali membuat seni tari yang mereka pentaskan pun memiliki makna yang dalam. Dilihat dari sisi lain pula, tari Kecak dapat dijadikan filosofi kehidupan bagi manusia, khususnya masyarakat Bali, yaitu dengan menarik intisari dari perkataan "orang baik akan selalu menang".

"Diakhir cerita tari Kecak, saat panglima Hanoman atau si Kerah Putih akan dibakar oleh raksasa Marica. Hanoman sebelumnya akan didoakan untuk meminta perlindungan para Dewa atau leluhur agar dilindungi dan tidak terluka saat mematikan kobaran api”.
Dari kutipan wawancara tersebut bahwasanya tari Kecak tergolong tarian yang sakral karena sang penari sebelum melakukan aksi mematikan kobaran api melakukan ritual untuk meminta perlindungan para Dewa atau leluhur terlebih dahulu. Selain itu, penari tersebut juga tidak terluka saat mematikan kobaran api. Hal ini tentunya menjadi daya tarik yang tinggi bagi penonton tari Kecak, karena sebuah pertunjukan kesenian yang berbasis tarian, memiliki nilai sakral yang dianggap tidak dapat dilakukan oleh sembarang orang. Selain itu, hal ini juga dapat dianggap sebagai atraksi dalam menonton tari Kecak.

"Tari Kecak awalnya berasal dari tari sakral Sang Hyang. Kalau tari Sang Hyang hanya dipertunjukkan pada hari-hari tertentu dalam budaya masyarakat Bali. Tapi pada tahun 1930-an ada seorang seniman Bali yang bernama Wayan Limbak bekerja sama dengan pelukis asal Jerman yang bernama Walter Spies menciptakan tarian yang bernama tari Kecak. Tari Kecak ini inspirasinya dari tari Sang Hyang dan di dalamnya disisipkan cerita epos Ramayana".

Pemaparan singkat key informant tersebut menegaskan bahwa tari Kecak merupakan hasil inovasi dari tari sakral Sang Hyang, yang kemudian tarian tersebut dikembangkan menjadi seni tari dengan latar cerita parahyangan (cerita Ramayana). Intinya, tari Kecak sendiri tetap memiliki nilai sakral dalam setiap pementasannya. Hanya saja pada saat ini, tari yang dikenal dengan istilah fire dance oleh wasatawan mancanegara ini sekarang dijadikan sebuah pertunjukan seni dengan daya tarik yang tinggi.

"Saat ini tempat-tempat yang ramai dikunjungi wisatawan juga menyediakan pentas tari Kecak. Pentas tari Kecak yang cukup ramai penonton seperti di Uluwatu, Garuda Wisnu Kencana, Pantai Pandawa dan Gianyar. Tiket nonton tari Kecak dari harga $R p 60.000$ per-orang sampai dengan $R p 120.000$ per-orang. Wisatawan dapat 
nonton tari Kecak dengan membeli tiket di loket atau mengikuti paket wisata tour yang meyediakan paket nonton tari Kecak. Hampir semua tempat penyedia jasa paket wisata tour menyediakan paket nonton tari Kecak".

Berdasarkan hal tersebut, masyarakat Bali memanfaatkan tari Kecak untuk mendapatkan penghasilan lebih, seni tari Kecak diperjualbelikan kepada wisatawan. Disisi lain, tempat wisata di Bali juga menarik wisatawan dengan menyuguhkan pentas tari Kecak. Hal ini dapat membuktikan bahwa seni tari Kecak merupakan lakon dari Bali yang dapat menjadi salah daya tarik bagi wisawatan dalam negeri maupun wisatawan mancanegara. Pemanfaatan ini tentunya juga memberikan nilai yang positif bagi pulau Bali. Karena dengan adanya daya tarik ini wisatawan yang berkunjung ke Bali semakin banyak, dan suguhan kesenian Bali juga lebih bervariasi.

\section{Key Informant 2:}

"Masyarakat di Bali takut dengan balasan karma. Sehingga ketika mereka yang akan melakukan perbuatan tidak baik, mereka cenderung berpikir dua kali sebelum melakukannya. Perbuatan baik akan dibalas dengan karma baik dan sebaliknya perbuatan jahat pun akan dibalas dengan karma buruk. Dalam cerita tari Kecak terkandung makna pesan untuk mengingatkan manusia tidak melakukan perbuatan jahat, jika mereka telah melakukan perbuatan jahat, mereka harus siap menerima akibatnya".

Berdasarkan jawaban tersebut semakin menegaskan masyarakat Bali memang sangat mempercayai karma. Mereka cenderung berpikir lebih jauh sebelum melakukan suatu tindakan yang tidak terpuji. Sehingga dalam seni tari Kecak pun diselipkan makna pesan untuk mengingatkan manusia terutama pada masyarakat Bali untuk tidak melakukan tindakan tidak terpuji. Dengan kata lain, tari
Kecak dapat dijadikan ajaran moral bagi masyarakat Bali secara turun menurun.

"Salah satu tujuan dari cerita tari Kecak ini untuk memberitahu manusia, bahwa kejahatan akan selalu dikalahkan oleh kebaikan. Cerita dalam tari Kecak ini berisi sabda yang dipesankan para Dewa untuk manusia. Alangkah baiknya setiap orang menanam kebaikan dan tidak melakukan perbuatan jahat agar dapat hidup dengan damai”.

Masyarakat Bali sangat menjunjung tinggi kepercayaan yang mereka anut. Sehingga dalam seni tari Kecak pun, mereka memasukkan pesan dari sabda para Dewa. Sehingga tidak hanya merupakan sebuah pertunjuakan seni, tetapi tari Kecak juga dapat dijadikan ilmu pengetahuan dari segi religi, terutama yang beragama Hindu untuk dapat mendalami ajaran agama tersebut.

"Tari Kecak disebut sakral karena tari kecak berasal dari tari Sang Hyang. Dimana pada tari Sang Hyang seorang yang kemasukan roh akan berkomunikasi dengan para Dewa atau leluhur yang disucikan. Penari ketika menginjak api juga tidak terbakar karena telah meminta perlindungan para Dewa atau leluhur".

Berdasarkan pendapat tersebut, ditegaskan bahwasanya tari Kecak merupakan tarian yang sakral karena asal usulnya yang berasal dari tarian sakral Sang Hyang. Pada saat penari melakukan aksi memadamkan api yang membara tetapi tidak terbakar, juga merupakan salah satu dari kandungan kesakralan yang ada dalam tari Kecak. Hal ini juga membuktikan bahwa tari Kecak tidak dipentaskan secara sembarangan. Walaupun sebagian orang mengatakan tarian ini sudah menjadi bagian komersil, namun dalam pementasannya tari Kecak tetap harus meminta restu dari para Dewa dan leluhur agar dilancarkan segala sesuatunya.

"Tari Kecak sudah dikenal sejak tahun 1930-an. Tari Kecak juga diajarkan di 
sekolah-sekolah. Disini adalah sekolah tari Kecak, jadi orang yang ingin belajar juga bisa. Banyak yang tertarik untuk belajar tari Kecak karena disini tari Kecak paling diminati dan tentunya merupakan lakon dari Bali. Disisi lain, karena kemasan tariannya yang unik tanpa menggunakan iringan musik seperti gamelan, melainkan menggunakan suara dari mulut”.

Peneliti melihat bahwa tari Kecak adalah seni yang dilestarikan secara turun menurun dari generasi ke generasi, bahkan tari Kecak diajarkan pada sekolah formal maupun tidak formal. Tari Kecak merupakan salah satu tarian Bali yang paling banyak diminati karena keunikan yang dimiliki. Tari Kecak yang merupakan lakon dari Bali, juga menarik kemauan masyarakat Bali untuk mempelajari tari Kecak karena dianggap lebih dikenal.

"Bisa dikatakan orang Bali hidup dari seni, pentas tari Kecak dijadikan sumber penghasilan bagi masyarakat tertentu. Jika pentas resmi dari pemerintah hanya diberikan anggaran $R p 5.000 .000$ untuk dibagi rata 100 orang, jadi masing-masing hanya mendapatkan Rp 50.000. Berbeda dengan pentas komersil, satu orang bisa mendapatkan Rp 600.000 dan apabila pada musim liburan ramai, seperti bulan juli, agustus dan September satu orang bisa mendapatkan Rp 1.000.000”.

Berdasarkan jawaban dari key informant peneliti melihat, bahwa sebagian besar masyarakat Bali hidup dari seni. Dimana sebagian besar masyarakat Bali mengandalkan seni sebagai penghasilan bagi kehidupan mereka sehari-hari. Banyaknya seni Bali terutama tarian tradisional (salah satunya tari Kecak) Bali telah dipentaskan secara komersil merupakan salah satu bukti masyarakat Bali hidup dari seni. Seni diperjualbelikan untuk wisatawan guna mendapatkan penghasilan yang dapat menunjang kehidupan. Disisi lain tari Kecak dapat dijadikan sumber mata pencaharian bagi seniman Bali yang menggeluti bidang seni ini. Sehingga dari tari Kecak dapat membantu perekonomian masyarakat Bali.

\section{Informan 1:}

"Orang jahat pasti ada, namanya juga manusia. Bukan hanya di Bali saja, pasti disetiap daerah juga ada orang jahat. Tapi biasanya tindakan kriminal di Bali jarang yang orang Bali asli, karena orang Bali takut dengan karma, sehingga setiap mereka mau melakukan kejahatan selalu berpikir panjang terlebih dahulu. Kalau di Bali motor yang diparkir di tepi jalan dengan kunci juga tidak akan hilang. Soalnya mereka tidak berani mengambil barang yang bukan milik mereka, takut kalau nanti mereka juga akan dibales sama orang lain dengan hal yang sama".

Berdasarkan jawaban informan peneliti memahami bahwa dalam kehidupan akan selalu ada sisi gelap dan sisi terang. Semua ada timbal baliknya, ada sebab dan akibat. Kebanyakan masyarakat Bali sangat percaya akan hal ini. Mereka takut akan karma, seperti ajaran dalam agama Hindu. Jika seseorang tidak ingin diperlakukan tidak baik oleh orang lain, maka ia tidak boleh memperlakukan orang lain dengan tidak baik. Setiap yang kita lakukan dan kerjakan tentunya akan ada balasan untuk diri kita sendiri. Seperti sikap saling hargamenghargai, apabila kita ingin dihargai oleh orang lain, tentunya kita harus terlebih dahulu menghargai orang lain tersebut.

"Orang Bali jarang yang rasis. Setiap orang kan punya hak yang sama dari Tuhan, semua manusia itu setara, jadi setiap orang juga berhak milih agama atau kepercayaan yang mereka inginkan. Kalau kita berbuat baik pasti Dewa juga bisa melihat walaupun tidak ada manusia yang melihat sendiri. Kita percaya Dewa akan melindungi orang yang baik. Jadi kita berbuat baik juga bukan karena ada yang melihat baru berbuat baik, tapi berbuat baik tanpa mengharapkan pamrih".

Berdasarkan jawaban informan peneliti melihat bahwa masyarakat Bali 
sangat mempercayai agama atau kepercayaan yang dianut. Selain itu, orang Bali sangat toleransi dan menghargai perbedaan yang ada disekitar mereka. Mereka percaya orang baik akan selalu dilindungi Dewa. Mereka tidak fanatik terhadap hal-hal yang tidak sesuai dengan ideologi yang dianut. Walaupun tidak menutup kemungkinan bahwa ada sebagian orang Bali yang fanatik akan kepercayaannya, namun niscaya orang tersebut tidak akan memperoleh kehidupan yang baik. Karena apa yang dilakukannya sudah tidak sesuai dengan ajaran para Dewa (ajaran agama Hindu yang menjadi agama mayoritas di pulau Bali).

"Tari Kecak adalah tarian biasa yang dapat dilakukan oleh semua orang, tidak ada yang sakral dalam tarian ini. Tidak ada juga syarat tertentu bagi seorang penari jika ingin ikut berpartisipasi dalam tarian”.

Pandangan informan tersebut berarti bahwa tari Kecak sebagai tarian yang murni berasal dari seni, sehingga setiap orang dapat mempelajarinya. Tidak ada unsur sakral yang terkandung dalam tarian Kecak. Dari informasi ini, peneliti juga melihat bahwa pada saat ini tari Kecak lebih dikenal dengan tarian kesenian, sehingga siapa saja boleh mempelajarinya, asalkan dengan niat yang baik. Selain itu hal ini juga dapat dikatakan menjadi daya tarik bagi para wisatawan. Karena sebagian besar wisatawan khususnya yang berasal dari mancanegara jika melihat kesenian yang ada di Bali ingin turut langsung merasakannya. Contohnya seperti tari Kecak ini, jika melihat pementasan tari Kecak, maka ada beberapa wisatawan mancanegara juga turut ingin melakukan gerakan yang terdapat dalam tari Kecak. Sehingga dari hal ini masyarakat Bali cukup mempunyai peluang untuk mendapat pendapatan lebih. Karena dari hal yang tarian yang diajarin tersebut, pengajar tari Kecak bisa mendapatkan uang lebih, atau yang lebih dikenal dengan istilah uang tip.
"Di Bali, tari Kecak merupakan tarian dengan peminat terbanyak dibanding tari lainnya. Semua orang Bali pasti pernah nonton tari Kecak, dari anak-anak sampai orang dewasa. Mereka dikenalkan tari Kecak sejak masih kecil”.

Berdasarkan jawaban tersebut, semua masyarakat Bali mengenal tari Kecak dengan cukup baik. Hal ini dikarenakan sejak kecil orang tua sudah mengenalkan seni tari Kecak kepada anak-anak mereka. Sehingga sampai saat ini seni tari Kecak dapat dikenal oleh semua kalangan masyarakat Bali. Dengan kata lain, masyarakat Bali sendiri tidak ingin menghilangkan atau memudarkan seni tari Kecak. Hal ini terbukti dari sejak anaknya masih kecil sudah dikenalkan dengan kesenian tari Kecak. Hal ini menjadikan dasar yang penting agar tarian ini tetap dapat dipentaskan atau dikenal orang banyak secara turun menurun.

"Anak-anak sekolah biasanya banyak yang ikut group tari Kecak. Mereka kalau pulang sekolah banyak waktu senggang jadi lumayan juga buat tambah-tambah pendapatan. Jadi kalau ingin beli sepeda motor gitu mereka pakai uang sendiri, tidak minta dari orang tua. Uang hasil tari biasa dibagikan setiap enam bulan sekali”.

Dari respon di atas, tergambar bahwa generasi muda (anak sekolah SMP dan SMA) di Bali juga memanfaatkan waktu senggang untuk ikut serta dalam pentas tari Kecak. Hal ini tentunya dengan tujuan untuk mendapatkan penghasilan tambahan. Penghasilan dari tari yang dibagikan setiap enam bulan sekali membuat tidak sedikit dari mereka mengambil kesempatan ini untuk menabung jika menginginkan barang yang ingin dibeli. Seperti yang juga dikatakan informan sebelumnya, tari kecak dapat dijadikan sumber pendapatan. Hal ini membuktikan pernyataan tersebut. Karena dengan berpartisipasi menjadi penari tari Kecak, menjadikan turunnya angka pengangguran di pulau Bali. 


\section{Informan 2:}

"Di agama Hindu, dikatakan manusia pada dasarnya tidak akan terhindar dari lingkaran karma. Apapun yang dilakukan, pasti ada hasil yang akan diterima nantinya. Karena itu, masyarakat Bali takut akan balasan karma".

Berdasarkan penjelasan singkat tersebut, juga ditegaskan bahwasanya masyarakat Bali dalam melakukan suatu tindakan selalu mengingat karma yang akan diterima nantinya. Lingkaran karma tetap menjadi kepercayaan dasar bagi masyarakat Bali. Oleh sebab itu, setiap tindakan dari masyarakat Bali benar-benar sudah difikirkan dengan matang dan tidak sembarangan.

"Melalui tari Kecak, sabda para Dewa dapat disampaikan. Sabda para Dewa mengajarkan manusia untuk tidak berbuat hal-hal yang tidak terpuji. Kalau makna yang ada dalam cerita tari Kecak, tidak boleh menginginkan barang milik orang lain yang tidak dimiliki, lalu jangan berusaha mendapatkannya dengan cara picik. Dalam tari Kecak sendiri ada diceritakan Rahwana yang terpikat oleh kecantikan Shinta, kemudian Rahwana menculik Shinta. Tapi pada akhirnya Rahwana dikalahkan juga oleh Rama suaminya Shinta, artinya kejahatan akan selalu dikalahkan".

Berdasarkan jawaban dari informan, peneliti melihat bahwa seni tari Kecak tidak terlepas dari kepercayaan yang dianut masyarakat Bali. Masyarakat Bali begitu menjunjung tinggi kepercayaan yang dianut, sehingga dalam seni tari pun terdapat sabda para Dewa yang mengingatkan manusia untuk tidak melakukan tindakan tidak terpuji. Dengan kata lain tari Kecak menjadi salah satu sumber ajaran moral dan didikan Agama bagi masyarakat Bali sendiri khususnya. Hal ini dapat diambil dari intisari cerita Ramayana yang dipentaskan melalui tari Kecak.

"Diakhir cerita ada pemain yang berperan sebagai Hanoman melakukan aksi memadamkan api yang sedang menyala dengan kaki tanpa alas. Pemainnya sebelum melakukan aksi akan melakukan ritual meminta perlindungan para Dewa, setelah melakukan ritual tidak akan terbakar atau terluka sedikitpun meski apinya cukup besar".

Berdasarkan jawaban dari informan peneliti melihat, bahwa tari Kecak memiliki makna yang sakral karena adanya ritual untuk meminta perlindungan para Dewa, dan ritual yang dilakukan tersebut membuktikan pemain tidak terluka saat memadamkan api dengan kaki tanpa alas. Sama seperti penjelasan dari informan sebelumnya, intinya walaupun pada saat ini tari Kecak berbasis seni tari, namun memiliki nilai sakral yang tinggi, sehingga penari tari Kecak yang ingin melakukan pementasan harus benar-benar memiliki hati yang baik pula.

"Tari Kecak disisipkan cerita parahyangan, yaitu cerita kerajaan masyarakat Bali. Tentunya melalui tari Kecak, cerita parahyangan Bali dapat dilestarikan kepada generasi muda dan diharapkan juga cerita parahyangan Bali tidak akan hilang begitu saja, tetapi justru terus diceritakan pada anak-anak supaya mereka juga memahami asal usul adat dan budaya asli Bali sendiri”.

Disini, peneliti memahami jika masyarakat Bali memiliki keinginan yang kuat untuk terus melestarikan adat dan budaya tradisional Bali. Mereka menginginkan adat dan budaya tradisional yang dimiliki tetap dikenal oleh keturunannya dan tidak hilang begitu saja. Karena membangun sebuah kepercayaan bukanlah sebuah hal yang mudah, maka daripada itu masayarakat Bali tidak menyiakan keadaan ini, yaitu dengan membudidayakan tari Kecak secara turun menurun sebagai salah satu hal yang dapat dijadikan pedoman kehidupan dalam mempelajari moral kehidupan dan hidup beragama. 
"Pentas tari Kecak komersil umumnya kerja sama dengan penyedia jasa paket tour, karena tari Kecak sebagai lakon dari masyarakat Bali, jadi hampir semua penyedia jasa paket tur masukkan 'list' tari Kecak sebagai salah satu tempat tujuan wisata. Hotel-hotel yang menyediakan jasa paket tour biasanya juga ada kerja sama dengan sanggar tari Kecak”.

Berdasarkan hal tersebut, tari Kecak merupakan tarian yang begitu terkenal dikalangan masyarakat Bali maupun wisatawan sehingga semua jasa paket wisata menyediakan paket nonton tari Kecak. Juga, merupakan salah satu bukti bahwa tari Kecak merupakan seni tari yang mengandung nilai ekonomi yang tinggi dimata masyarakat Bali. Dengan kata lain, dari sebuah pementasan tari Kecak dapat menghasilkan pendapat yang lumayan untuk membantu perekonomian masyarakat Bali. Sehingga dari pementasan tari Kecak, dapat dikatakan masyarakat Bali dapat memperbaiki keadaan ekonomi keluarganya.

\section{Informan 3:}

"Menurut saya, hal yang penting adalah kita tidak boleh berbuat jahat kepada orang lain, jika kita tidak bisa menjadi orang yang baik. Kita semua tentunya tidak ingin orang lain bersikap tidak baik pada kita, untuk itu sebaiknya kitajuga tidak boleh bersikap tidak baik pada orang lain. Hidup memang selalu berlaku timbal balik, kita tidak bisa menyangkal hal tersebut, karena itu sudah merupakan hukum alam".

Berdasarkan jawaban dari informan peneliti menyimpulkan bahwa secara tidak langsung informan mengatakan bahwa dalam kehidupan ini terdapat sebab akibat. Dimana jika kita orang tidak ingin diperlakukan tidak baik oleh orang lain, kita juga tidak boleh memperlakukan orang lain dengan tidak baik. Istilah memberi tanpa mengharapkan pamrih hingga saat ini masih menjadi perkataan yang memiliki makna dalam bagi masyarakat Bali. Karena mereka percaya bahwa melakukan yang baik akan menerima hal yang baik pula.

"Itu adalah kepercayaan yang mereka miliki. Saya percaya agama tidak mengajarkan orang merebut barang milik orang lain. Menurut saya, ini berlaku universal bukan hanya pada ajaran agama Hindu atau berlaku untuk masyarakat di sini saja tapi bagi semua orang”.

Berdasarkan jawaban dari informan peneliti memaknai bahwa informan menyetujui makna kepercayaan masyarakat Bali yang terkandung dalam tari Kecak. Karena menurut informan bahwa pesan moral yang tersirat dalam pementasan tari Kecak berlaku secara universal, yaitu tidak hanya berlaku bagi masyarakat Bali yang erat dengan kepercayaannya, tetapi juga berlaku bagi agama lain yang pada dasarnya semua agama mengajarkan sisi kebaikan.

"Tarian ini menghibur, tetapi juga ada sisi yang cukup menegangkan. Ketika salah satu pemain mematikan api tanpa menggunakan alas kaki atau apapun. Ini menegangkan tapi juga bikin takjub, karena apinya tidak kecil. Agak kearah yang bersifat mistik".

Berdasarkan jawaban dari informan, tari Kecak dianggap sebagai tarian yang bersifat sakral karena aksi memadamkan api yang dilakukan pemain tanpa terluka. Hal mistik selalu menjadi bagian dari budaya Bali. Di pulau ini tidak heran jika wisatawan banyak menemukan pohon besar yang berada dipinggir jalan dikasih sesajen (canang) dan kemudian disembah atau dengan istilah lain disembahyangkan. Bagi masyarakat Bali yang melakukan hal ini percaya bahwa pohon besar tersebut memiliki penunggu yang dapat mendatangkan rezeki maupun kebahagian. Dari hal ini dapat dikatakan merupakan hal yang mistik. Sama seperti dengan tarian pada tari Kecak. Jika dilihat dari segi logika, jika seseorang yang menginjak atau bersentuh dengan api tentunya akan terluka. Akan tetapi hal ini tidak berlaku dalam pementasan tari Kecak. Karena pada 
pertunjukannya penari yang melakukan hal tersebut tidak terluka sama sekali. Maka daripada itu, ada juga yang menganggap bahwa tari Kecak merupakan tarian kesenian yang memiliki nilai mistik.

"Tari Kecak sangat menakjubkan, dimana tanpa bantuan alat musik mereka dapat menciptakan nada yang berirama dengan menggunakan suara dari mulut saja. Ini sangat unik dan menarik. Dengan penari yang hampir seratus orang, mereka dapat kompak menjadi satu menciptakan tarian yang tidak membosankan. Pakaian dan aksesoris yang mereka gunakan sangat indah. Orang juga dapat memahami apa yang maksud tarian yang dipentaskan dengan bantuan yang diberikan oleh penari dalam bahasa inggris. Penonton dapat mengikuti jalan cerita dan tidak kebingungan dengan apa yang mereka ingin sampaikan".

Berdasarkan deskripsi tersebut diketahui bahwa informan sangat tertarik dengan seni tari Kecak yang dipentaskan. Hal ini terlihat dimana informan dapat menjelaskan tari Kecak dengan cukup detail. Dapat dikatakan salah satu hal yang menjadi daya tarik tari Kecak adalah jalan atau alur ceritanya mudah dipahami. Sehingga penonton dapat dengan mudah menelaah arti dari setiap gerak tari yang dipentaskan.

"Banyak promosi dengan poster yang digantung di jalan-jalan, saya ada lihat dibeberapa tempat lain seperti di pantai. Karena ada dimana-mana jadi saya penasaran juga, makanya saya coba beli. Harga tiketnya tidak terlalu mahal hanya $R p$ 100.000”.

Berdasarkan jawaban dari informan peneliti menilai bahwa masyarakat Bali juga menggunakan media seperti poster untuk memberitahu wisatawan mengenai pentas tari Kecak yang dapat disaksikan secara langsung. Dari sini peneliti melihat bahwa masyarakat Bali benar-benar memanfaatkan tari Kecak untuk dijadikan 'ladang' pencarian pendapatan. Hal ini mengingat bahwa masyarakat Bali harus benar-benar memanfaatkan segala sesuatu yang dapat dijadikan uang disekitarnya. Karena biaya yang dikeluarkan masyarakat Bali untuk kehidupan sehari-hari tidak murah. Terlebih biaya yang diperlukan untuk keperluan sembahyang cukup besar. Mengingat di Bali begitu banyak peringatan ritual sembahyang yang harus dilakukan, seperti hari raya Nyepi, Galungan, Kuningan, bahkan ritual kematian untuk melakukan Ngaben membutuhkan dana yang besar.

\section{Informan 4:}

"Percaya tidak percaya, setiap kejadian memang ada sebab akibatnya, hal ini berkaitan dengan moral kemanusiaan. Semua orang harusnya pasti tahu dan mengerti, ketika kita menanam padi tidak mungkin akan berbuah mangga dan begitupun sebaliknya".

Berdasarkan jawaban dari informan peneliti menyimpulkan, bahwa informan percaya adanya sebab akibat dalam setiap kejadian. Informan mengaitkan sebab akibat dengan moral kemanusiaan.

"Ya, yang saya tahu agama apapun memang selalu mengajarkan orang untuk berbuat baik dan jika bisa sebanyak mungkin. Kalau di film-film orang jahat yang menyakiti orang baik pasti akhirnya menyesal dan minta maaf".

Berdasarkan jawaban dari informan peneliti menyimpulkan, bahwa informan menyetujui bahwa orang jahat yang jahat akan selalu dikalahkan oleh orang yang baik. Bahkan informan ini mengaitkan cerita yang terdapat pada tari Kecak dengan kehidupan yang nyata dan juga cerita yang ada di filmfilm. Sehingga dapat diambil kesimpulan bahwa pesan yang tersirat pada tari Kecak benar-benar apa adanya seperti yang terjadi dalam kehidupan nyata, bukan merupakan sebuah pemikiran fiktif atau hanya berupa khayalan seniman.

"Tidak terlihat ada kandungan cerita yang bersifat sakral, ini lebih seperti sebuah 
pentas dramamusikal dan sedikit sulap dengan menggunakan api."

Berdasarkan jawaban dari informan peneliti mengetahui bahwa informan tidak menyetujui adanya kesakralan dalam tari Kecak, karena penari yang memadamkan api disamakan dengan orang yang melakukan sulap dengan menggunakan api. Seperti informan sebelumnya yang menganggap tari Kecak memiliki nilai mistik, informan ini melihat tari Kecak sebagai sebuah pertunjukan seni yang memiliki nilai sulap ataupun trik dalam mematikan api. Hanya saja sedikit orang yang beranggapan seperti ini karena pada dasarnya tari Kecak memiliki nilai sakral yang tinggi karena berasal dari tarian Shang Hyang.

"Tari ini lebih menarik kalau kita nontonnya secara langsung. Meski seni dan budaya mereka kelihatannya masih sangat kental, tapi tarian yang disajikan tidak membosankan dan cukup menghibur. Penari yang berinteraksi langsung dengan penonton membuat penonton bisa fokus dengan tarian yang disajikan. Terutama tari Kecak ini memiliki kandungan nilai moral kemanusiaan".
Peneliti menilai bahwasanya seni dan budaya yang terdapat pada tari Kecak dapat menjadi daya tarik wisatawan, terutama moral yang terkandung di dalamnya. Sehingga dari menonton pementasan tari Kecak penonton dapat mengambil intisari filosofi kehidupan yang baik.

"Nonton tari Kecak sudah masuk dalam daftar tempat kunjungan paket tur. Ada beberapa pilihan paket yang disediakan jasa paket tur, tapi hampir semua paket sudah termasuk nonton tari Kecak. Banyak orang yang bilang. Kalau pergi ke Bali, wajib nonton tari Kecak, karena tari Kecak sangat terkenal di Bali".

Berdasarkan jawaban dari informan peneliti menyimpulkan, bahwa tari Kecak merupakan seni tari yang banyak dikenal wisatawan. Oleh karena itu, banyak penyedia jasa tur yang memanfaatkan hal ini untuk menarik wisatawan dengan tujuan mencari keuntungan ekonomi yang lebih besar.

\section{Pembahasan}

Berikut kategorisasi yang peneliti dapatkan dari hasil pengamatan dan wawancara yang telah dilakukan:

Tabel 1. Kategorisasi Makna Pesan Tari Kecak

\begin{tabular}{llrrrrrrr}
\hline NNo & \multicolumn{1}{c}{ Deskripsi } & \multicolumn{8}{c}{ Narasumber } \\
& & KI1 & KI2 & I1 & I2 & I3 & I4 \\
\hline 1. & Menghindari Karma & $\checkmark$ & $\checkmark$ & $\checkmark$ & $\checkmark$ & $\checkmark$ & $\checkmark$ \\
2. & Kepercayaan & $\checkmark$ & $\checkmark$ & $\checkmark$ & $\checkmark$ & $\checkmark$ & $\checkmark$ \\
3. & Sakral & $\checkmark$ & $\checkmark$ & -- & & $\checkmark$ & $\checkmark$ & -- \\
4. & Seni \& Budaya & $\checkmark$ & $\checkmark$ & $\checkmark$ & $\checkmark$ & $\checkmark$ & $\checkmark$ \\
5. & Ekonomi & $\checkmark$ & $\checkmark$ & $\checkmark$ & $\checkmark$ & $\checkmark$ & $\checkmark$ \\
& & & & & & & \\
\hline
\end{tabular}

Sumber: Hasil Penelitian Peneliti

Dari kelima makna pesan yang berhasil digali peneliti dari semua narasumber, terdapat temuan sebagai berikut: a. Makna pesan menghindari karma, kepercayaan, seni dan budaya, dan ekonomi didapatkan dari semua narasumber. 
Berdasarkan teori 'Pengertian Semantik' yang dikemukakan oleh Osgood, teori ini berhubungan dengan cara-cara mempelajari makna dan bagaimana makna tersebut berhubungan dengan pemikiran dan perilaku. Dari kelima kategorisasi yang peneliti temukan, empat diantaranya memiliki nilai yang lebih kuat. Hal ini berarti makna pesan yang ingin disampaikan oleh komunikator dapat diterima dengan cukup efektif. Selain itu, makna pesan tersebut juga telah memberikan efek pada pemikiran dan perilaku individu. Hal yang paling menonjol adalah dimana masyarakat Bali sangat percaya jika orang baik akan dilindungi oleh para Dewa, sehingga mereka pun berusaha untuk selalu melakukan hal-hal baik. Pada tari Kecak ini, adegan yang terdapat makna pesan tersebut, yaitu pada saat Rama berhasil menolong Shinta dari cengkraman Rahwana dengan mengalahkannya. Intinya tari Kecak memiliki nilai kepercayaan yang tinggi, yang dapat membuat penontonnya percaya bahwa sesuatu yang baik akan menang, dan juga sekaligus membenarkan bahwa karma masih berlaku didalam 'roda' kehidupan.

Jika dilihat dari segi ekonominya, masyarakat Bali benar-benar memanfaatkan tari Kecak sebagai salah satu mata pencaharian mereka. Karena dengan menjadi penari tari Kecak dapat menghasilkan pendapatan yang lumayan besar. Hal ini juga mengingat bahwa biaya hidup khususnya bagi masyarakat Bali yang beragama Hindu cukup tinggi. Karena kepercayaan yang mengharuskan mereka untuk berkerja keras. Dalam kurun waktu setahun begitu banyak ritual keagamaan yang harus dilakukan, seperti hari raya Nyepi, Galungan, Kuningan, Pager Wesi dan ritual keagamaan lainnya yang membutuhkan dana yang besar untuk menyiapkan pesembahan kepada para Dewa dan para leluhur. Bahkan untuk keseharian masyarakat Bali juga membutuhkan biaya yang cukup tinggi untuk melakukan sembahyang. Karena dalam setiap prosesi sembahyang mereka memerlukan sesajen atau masyarakat Bali menyebutnya dengan canang, yang mana berisikan bunga, kemenyan, permen dan lainnya yang merupakan persembahan kepada para Dewa. Sehingga dengan memanfaatkan tari Kecak sebagai salah satu sumber mata pencaharian, cukup membantu kondisi perekonomian masyarakat yang berdomisili di Pulau Bali, khususnya masyarakat pulau Bali yang beragama Hindu.

b. Makna pesan tentang kesakralan tidak didapatkan dari semua narasumber yaitu informan pertama dan informan ke empat. Alasannya:

Menurut informan pertama, meskipun tari Kecak awalnya berasal dari tari Sang Hyang, tari Kecak tetap tidak dapat dikatakan bersifat sakral. Hal ini karena informan menilai bahwa tari Kecak dengan tari Shang Hyang mempunyai perbedaan yang cukup jauh. Tari Shang Hyang tidak dipertunjukkan untuk masyarakat umum dan hanya ada pada hari keagamaan umat Hindu masyarakat Bali. Orang yang menarikan tari Shang Hyang pun harus memenuhi syaratsyarat tertentu, sehingga tidak semua orang dapat menarikan tari Shang Hyang. Berbeda dengan tari Shang Hyang, tari Kecak dapat disaksikan oleh masyarakat secara umum dan pertunjukkannya juga dikomersilkan. Selain itu, semua orang dapat ikut menari, baik laki-laki, perempuan, anak-anak maupun orang dewasa.

Menurut informan ke-4, tari Kecak tidak mengandung cerita yang bersifat sakral karena pentas tari Kecak dianggap seperti sebuah drama musikal dan sedikit sulap dengan menggunakan api. Informan ke empat mengatakan, bahwa pentas drama musikal yang mencampurkan sulap dengan menggunakan api banyak dilakukan di China, bahkan pentas akrobatik juga 
banyak yang menggunakan api. Bagi informan, aksi memadamkan api oleh salah satu penari dalam tari Kecak tersebut bukan hal yang luar biasa.

Walaupun kedua informan ini menganggap tari Kecak bukanlah tarian yang sakral, tetapi sebagian besar masyarakat Bali percaya bahwa tarian ini memiliki nilai sakral. Dengan memasukkan unsur mistik didalamnya seperti mematikan api tanpa alas kaki, mereka percaya bahwa tari Kecak harus mendapat restu dari para Dewa dan juga para leluhur sebelum melakukannya.

\section{PENUTUP}

\section{Simpulan}

Peneliti memberikan kesimpulan bahwa makna/pesan yang terkandung dalam tarian Kecak mengandung lima unsur yaitu; menghindari karma, kepercayaan (value), sakral, seni dan budaya, dan ekonomi.

\section{Saran}

1. Makna pesan yang terkandung dalam tari Kecak dapat lebih diperjelas agar wisatawan dari berbagai suku dan budaya yang berbeda dapat lebih memahami apa yang ingin disampaikan dalam tari Kecak. Bila perlu, dalam setiap pementasan tari Kecak dibutuhkan seorang penerjemah cerita atau yang layaknya orang Indonesia menyebutnya dengan dalang, jika dalam istilah perwayangan adat Jawa.

2. Moderator dalam pentas tari Kecak sebaiknya menggunakan orang di luar dari penari agar penari dapat fokus terhadap tarian yang mereka lakukan. Karena pada saat ini yang menjadi moderator adalah mereka yang juga menjadi bagian dari penari.

\section{DAFTAR PUSTAKA}

Alo, Liliweri. (2003). Dasar-Dasar Komunikasi Antar Budaya. Yogjakarta: Pustaka Pelajar.

Alwi, Hasan. (2007). Kamus Besar Bahasa Indonesia. Edisi Keempat. Jakarta: PT. Balai Pustaka.

Arikunto, Suharsimi. (2010). Prosedur Penelitian: Suatu Pendekatan Praktik. Edisi Revisi. Jakarta: Rineka Cipta.

Darmastuti, Rini. (2013). Mindfullness Dalam Komunikasi Antarbudaya. Yogjakarta: Buku Litera.

Denzin, N. K., dan Y. S. Lincoln. (2009). Handbook Of Qualitative Research. Yogyakarta: Pustaka Pelajar.

Effendy, Onong Uchjana. (2001). Ilmu Komunikasi Teori dan Praktek. Bandung: PT. Remaja Rosdakarya.

Griffin, E.M. (2003). A First Look at Communication Theory. London: McGrraw-Hill Companies.

http://elib.unikom.ac.id/download.php?id=2 62724 (diakses 20/1/2017 jam 22.02 WIB)

http://elib.unikom.ac.id/download.php?id=2 08909 (diakses 20/1/2017 jam $00.26 \mathrm{WIB})$

http://eprints.uny.ac.id/23883/4/BAB\%20II. pdf (diakses 16/1/2017 jam 22.10 WIB)

http://kbbi.co.id/arti-kata/metode (diakses 11/1/2016 jam 23.43 WIB)

http://kebudayaanindonesia.net/kebudayaan /890/tari-kecak (diakses 11/2/2016 jam 02.58 WIB)

http://library.umn.ac.id/eprints/1164/(diakse s20/1/2017 jam 21.04 WIB

Littlejohn, Stephen W., dan Karen A. Foss. (2014). Teori Komunikasi (Theories of Human Communication). Jakarta: Salemba Humanika.

Poerwandari, E. K. (2005). Pendekatan Kualitatif Untuk Penelitian Perilaku Manusia. Edisi Ketiga. Depok: LPSP3 Fakultas Psikologi Universitas Indonesia. 
Pujileksono, Sugeng. (2015). Metode Penelitian Komunikasi Kualitatif. Malang: Instrans Publishing.

Sugiyono. (2013). Metode Pendidikan (Pendekatan Kuantitatif, Kualitatif, Dan $R \& D)$, Alfabeta, Bandung

Suwandi, Sarwiji. (2008). Semantik Pengantar Kajian Makna. Yogjakarta: Media Perkasa.
West, Richard, dan Lynn H. Turner. (2010). Pengantar Teori Komunikasi. "Introducing Communication Theory: Analysis And Application". Jakarta: Salemba Humanika.

Wood, Julia. (2013). Komunikasi Teori dan Praktik (Komunikasi Dalam Kehidupan Kita). Jakarta: Salemba Humanika. 